\title{
TINDAK PIDANA EKSPLOITASI SEKSUAL (PERKOSAAN) OLEH ORANG TUA TIRI TERHADAP ANAK DIBAWAH UMUR (STUDI PUTUSAN PN MEDAN NO. 1599/PID. B/2007/PN Mdn)
}

\author{
Oleh: \\ Muhammad Ansori Lubis ${ }^{1)}$ \\ Lestari Victoria Sinaga ${ }^{2)}$ \\ Universitas Darma Agung, Medan ${ }^{1,2)}$ \\ E-mail: \\ ${\frac{\text { ansoriboy67@gmail.com }}{\text { Missthary35@gmail.com }}{ }^{\text {2) }}}^{\text {2) }}$
}

\begin{abstract}
This study aims at finding how the Legal Arrangement of Sexual Exploitation (Rape) Against Minors by Stepparents, the factors causing sexual exploitation (rape) of stepchildren, and how the application of criminal law to the crime of sexual exploitation (rape) in the PN MEDANNO ruling. 1599 / Pid. B / 2007 / PN MDN. In this study, a normative research method is used, using the laws and literature study by collecting legislation Law Number 35 of 2014 concerning Child Protection, which results in research that is the case decision number 1599 / PID. B / 2007 / PN Mdn and legal considerations judges impose sentences. Application of material criminal law against the perpetrators of sexual violence against children in decision number 1599 / PID. B / 2007 / PN Mdn is based on legal facts both through witness statements, defendant statements, and evidence. In addition, it is also based on juridical considerations namely prosecution and prosecution demands. In this case, the prosecutor used three indictments, namely the public prosecutor's indictment, the third indictment violated article 82 paragraph (1) Jo article $76 E$ RI Act No. 35 of 2014 concerning child protection. Sentenced to 10 years imprisonment for the defendant and a fine of Rp. 600,000,000, - (Six Hundred Thousand Rupiah) provided that if the fine is not paid then it must be replaced with imprisonment for 3 months.
\end{abstract}

Keywords: Criminal Sanctions, Perpetrators of Violence, Child Sexual

\begin{abstract}
ABSTRAK
Rumusan masalah dalam penelitian ini adalah: Bagaimana Pengaturan Hukum Tindak Pidana Eksploitasi Seksual (Perkosaan) Terhadap Anak Di Bawah Umur Oleh Orang Tua Tiri, Apakah faktor penyebab terjadinya eksploitasi seksual (perkosaan) terhadap anak tiri? Bagaimana penerapan hukum pidana terhadap tindak pidana eksploitasi seksual (pemerkosaan) dalam putusan PN MEDANNO. 1599/Pid. B/2007/PN MDN? Dalam penelitian ini menggunakan metode penelitian normatif yaitu menggunakan peraturan perundang-undangan dan studi kepustakaan dengan mengumpulkan peraturan perundangundangan UU Nomor 35 Tahun 2014 tentang Perlindungan anak, dimana menghasilkan penelitian yakni putusan perkara nomor 1599/PID. B/2007/PN Mdn dan pertimbangan hukum hakim menjatuhkan hukuman. Penerapan hukum pidana materil terhadap pelaku
\end{abstract}


tindak pidana kekerasan seksual terhadap anak dalam putusan nomor 1599/PID. B/2007/PN Mdn yaitu didasarkan pada fakta-fakta hukum baik melalui keteranganketerangan saksi, keterangan terdakwa, maupun alat-alat bukti. Selain itu, juga didasarkan pada pertimbangan yuridis yaitu dakwaan dan tuntutan jaksa. Dalam kasus ini, jaksa menggunakan tiga dakwaan yaitu penuntut umum mendakwakan, dakwaan Ketiga melanggar pasal 82 ayat (1) Jo pasal 76E Undang-Undang RI no.35 Tahun 2014 tentang perlindungan anak. Menjatuhkan pidana penjara terhadap terdakwa selama 10 Tahun dan pidana denda sejumlah Rp. 600.000.000,-( Enam Ratus Ribu Rupiah ) dengan ketentuan jika denda tersebut tidak dibayar maka harus diganti dengan pidana kurungan selama 3 Bulan.

\section{Kata Kunci : Sanksi Pidana, Pelaku Kekerasan, Seksual Anak.}

\section{PENDAHULUAN}

Perkosaan terhadap anak di bawah umur dalam hal hubungan keluarga atau ayah dengan anak di atur secara khusus dalam Undang-Undang No. 23 tahun 2002 tentang perlindungan anak.Dalam dunia eksploitasi seksual perlu adanya perhatian dari lingkungan maupun ruang lingkup keluarga itu sendiri dengan mementingkan komitmen-komitmen yang dapat membantu keutuhan keluarga sehingga tidak menimbulkan perkosaan oleh ayah tiri terhadap anak dibawah umur.

Perlu adanya campur tangan pemerintah seperti penyuluhan maupun menginstruksikan aparat keamanan guna menjaga kejadian-kejadian yang melanggar tindak pidana eksploitasi sosial yang khususnya perkosaan oleh ayah tiri terhadap anak dibawah umur, agar anak dibawah umur tidak menjadi pemuas nafsu baik dikalangan keluarga sendiri maupun orang banyak seperti sebuah tempat yang mempekerjakan anak dibawah umur menjadi pekerja seks.

Bahwa untuk menjegah terjadinya tindak pidana ekxploitasi seksual (pemerkosaan) diperlukan pendalaman mengenai agama dengan memiliki wawasan yang luas tantang agama.

\section{TINJAUAN PUSTAKA}

Perkosaan (Rapping) adalah penetrasi alat kelamin dengan paksaan, perkosaan dibagi tiga yaitu :

a) Common Law Rape adalah perkosaan dengan wanita yang cukup umur.

b) Statutory rape adalah perkosaan yang dilakukan di bawah umur, yang berarti memiliki unsur-unsur phedofilia.

c) True rape adalah ketika pemerkosaan melakukan kegiatannya secara berulang kali untuk menyalurkan nafsu seksualnya bersama-sama dengan agresifitas.

\section{Perkosaan menurut KUHP}

Sedangkan menurut KUHP sendiri perkosaan terdapat dalam pasal 285 KUHP yang berbunyi:

"Barangsiapa dengan kekerasan atau ancaman kekerasan memaksa perempuan yang bukan isterinya bersetubuh dengan dia, dihukum, karena memperkosa, dengan hukuman penjara selama-lamanya dua belas tahun".

Menurut KUHP itu sendiri perkosaan di bawah umur terdapat dalam pasal 287Kitab Undang-undang Hukum Pidana ( KUHP) yang berbunyi:

a Barangsiapa bersetubuh dengan perempuan yang bukan isterinya, 
sedang diketahuinya atau harus patut disangkanya, b11ahwa umur perempuan itu belum cukup 15 tahun kalau tidak nyata berapa umurnya, bahwa perempuan itu belum masanya untuk kawin, dihukum penjara selamalamanya sembilan tahun.

b Penuntutan hanya dilakukan kalau ada pengaduan, kecuali kalau umurnya perempuan itu belum sampai 12 tahun atau jika ada salah satu hal yang tersebut pada pasal 291 dan 294".

Unsur-unsur Pasal 287 :

- Unsur subjektif : Perbuatan perzinahan, Perbuatan pencabulan, Penuntutan, diancam dengan pidana penjara.

- Unsur objektif : Barangsiapa, atas pengaduan, umurnya masih dibawah umur, sesuai dalam pasal ini bahwa pasal 287 termasuk delik biasa : Pasal 287 pencabulan, perzinahan.

Delik yang dikualifikasi (dikhususkan), kecuali jika umur wanita belum sampai dua belas tahun atau jika ada salah satu hal berdasarkan pasal 291 dan pasal 294. Alasan : Suatu perbuatan yang dilarang oleh suatu aturan-aturan pidana dan apabila ada perbuatan yang memberatkan misalnya ada penganiyaan didalamnya maka perbuatan itu akan mendapatkan sanksinya yang lebih berat. Sedangkan dalam pasal 294 Kitab Undang-undang Hukum Pidana (KUHP) :

1. Barangsiapa melakukan perbuatan cabul dengan anaknya yang belum dewasa, anak tiri atau pungutnya, anak peliharaannya, atau dengan seseorang yang belum dewasa yang dipercayakan padanya untuk ditanggung, dididik atau dijaga, atau dengan bujang atau orang sebawahnya yang belum dewasa, dihukum penjara selamalamannya tujuh tahun.

2. Dengan hukuman yang serupa dihukum :

a. Pegawai negeri yang melakukan perbuatan cabul dengan orang yang dibawah perintahnya atau dengan orang yang dipercayakan atau diserahkan padanya untuk dijaga.

b. Pengurus, tabib, guru, pegawai, mandor atau bujang dalam penjara, rumah tempat melakukan pekerjaan untuk negeri, rumah pendidikan, rumah piatu, rumah sakit, rumah sakit ingatan atau balai derma, yang melakukan pencabulan dengan orang yang ditempatkan disitu.

Dalam pasal 294 ayat 1 diatas terdapat unsur-unsur subjektif dan objektif.

Unsur-unsur subjektifnya adalah :

1) Melakukan perbuatan cabul, yaitu perbuatan asusila dan termasuk tindak pidana yang dengan niat seseorang melakukan terhadap orang lain dalam hal ini merampas kebebasan seseorang dan menimbulkan kerugian bagi orang tersebut. Dengan orang yang belum dewasa, yaitu melakukan perbuatan asusila terhadap orang yang belum dewasa atau terhadap anak dibawah umur yang seharusnya dipelihara dan dijaga.

Unsur objektifnya adalah :

Anak dibawah umur yang dicabuli, yaitu perbuatan yang melanggar hukum yang dilakukan oleh seseorang terhadap anak dibawah umur dengan cara mencabuli sehingga anak tersebut merasa haknya dirampas.

Inses biasanya terjadi antara saudara laki-laki dengan adik kandung atau tiri, ayah dengan anak kandung atau anak tiri, ayah dengan anak angkat atau 
anak adopsi, kakek dengan cucu, paman dengan keponakan kandung atau tiri dan laki-laki lain yang sudah seperti keluarga, yang posisinya dipercaya.

Pengertian yang luas dari inses juga mencakup hubungan seksual yang dilakukan oleh orang yang diberikan kepercayaan untuk mengasuh seseorang misalnya guru terhadap murid atau, pendeta/ulama terhadap anak asuh nya dan lain-lain.

Namun, pada dasarnya hubungan inses yang paling umum terjadi yaitu antara anggota keluarga antara anak dengan ayah kandung atau tiri, maupun antar anak dengan ibu kandung atau tiri, dan antara saudara kandung.

Inses dilakukan dengan berbagai pola, misalnya disertai dengan kekerasan fisik, non fisik atau rayuan untuk membuat korban tidak berdaya sebelum, saat atau sesudah kejadian. Adakalanya inses terjadi tanpa menggunakan unsur kekerasan, paksaan atau rayuan, tetapi berdasarkan rasa saling suka meskipun ini jarang terjadi.

Wirdjono Prodjodikoro, menyatakan bahwa Tindak Pidana adalah suatu perbuatan yang pelakunya dapat dikenakan hukum pidana. Untuk istilah "Tindak" memang telah lazim dalam peraturan perundang-undangan kita, bahkan dapat dikatakan sebagai istilah resmi dalam perundang-undangan kita, seperti dalam KUHP dan peraturanperaturan tindak pidana khusus.

Pengertian anak di bawah umur di sini mencakup batas usia anak. Batas usia anak memberikan pengelompokan terhadap seseorang untuk dapat disebut sebagai anak di bawah umur. Yang dimaksud dengan batas usia anak adalah pengelompokan usia maksimum sebagai wujud kemampuan anak dalam status hukum.
Mengenai tentang anak ini dalam perumusannya tidak ada keseragaman, tingkat usia seseorang dapat dikategorisasikan sebagai anak di bawah umur antara suatu negara dengan negara lain cukup beraneka ragam. Di Amerika Serikat, 27 negara bagian menentukan anak di bawah umur antara 8-18 tahun, sementara 6 negara bagian menentukan anak di bawah umur antara 8-17 tahun.

Di Inggris ditentukan anak dibawah umur antara 12-16 tahun, Belanda menentukan anak di bawah umur antara 12-18 tahun, negara-negara Asia, antara lain Sri Lanka menentukan anak dibawah umur antara 8-16 tahun, di Korea dan Jepang menentukan anak dibawah umur antara 14-20 tahun.

Singapura menentukan anak dibawah umur antara 1-16 tahun. Sementara di Indonesia mengenai pengertian anak dibawah umur berbeda jika dilihat menurut Hukum Adat, Hukum Perdata, Hukum Pidana dan menurut undangundang nomor 23 tahun 2002 tentang perlindungan anak.

Menurut hukum adat tidak ada batasan umur yang pasti bilamana dikatakan seseorang itu masih dibawah umur atau tidak, hal ini dapat dilihat dari ciri-ciri Ter Haar dalam bukunya "BEGINSELLEN EN STELSEL VAN HET ADATRECHT” Mengatakan:

"seseorang sudah dewasa menurut hukum adat di dalam persekutuan hukum yang kecil adalah pada seseorang baik perempuan maupun laki-laki apabila dia sudah kawin dan disamping itu telah meninggalkan orang tuanya ataupun rumah mertua dan pergi pindah mendirikan kehidupan rumah keluarganya sendiri”. 
Menurut Hukum Perdata Mengenai pengertian anak di bawah umur (belum dewasa) tercantum dalam pasal 330 KUHPerdata yang bunyinya sebagai berikut :

"Belum dewasa adalah mereka yang belum mencapai umur genap dari dua puluh satu tahun, dan tidak lebih dahulu kawin. Apabila perkawinan itu dibubarkan sebelum umur mereka genap dua puluh satu tahun maka mereka tidak kembali lagi dalam kedudukan belum dewasa. Mereka yang belum dewasa dan tidak berada dalam kekuasaan orang tua, berada di bawah perwalian atas dasar dan dengan cara sebagaimana teratur dalam bagian ke-tiga, ke-empat, ke-lima, keenam,bab ini."

Jadi yang dimaksud belum dewasa (di bawah umur) berdasarkan pasal 330 KUHPerdata adalah :

1. Belum penuh berumur 21 tahun

2. Belum pernah kawin

Menurut Hukum Pidana, Berdasarkan KUHPidana bahwa mengeai anak di bawah umur (belum dewasa) adalah mereka yang berusia di bawah 16 tahun. Dalam pasal 45 KUHP menyebutkan :

"Jika seseorang yang belum dewasa dituntut karena perbuatan yang dikerjakannya ketika umurnya enam belas tahun, hakim boleh memerintahkan sitersalah itu dikembalikan kepada orang tunya, wali, atau pemeliharaanya dengan tidak dikenakan suatu hukuman, yakni jika perbuatan itu masuk bagian kejahatan atau pelanggaran yang diterangkan dalam pasal 489, 490, 492, 496, 497, 503-505, 514, 417-519, 526,
531，532，536, dan 540 dan perbuatan itu dilakukannya sebelum lalu 2 tahun sesudah keputusan dahulu yang menyalahkan dia melakukan salah satu pelanggaran ini atau sesuatu kejahatan; atau menghukum anak yang bersalah itu."

Menurut Undang-undang nomor 23 tahun 2002 tentang Perlindungan Anak, Yang dimaksud dari Anak di dalam undangundang nomor 23 tahun 2002 perlindungan anak bab I Ketentuan umum pasal 1 nomor 1 adalah seseorang yang belum berusia 18 (delapan belas) tahun, termasuk anak yang masih dalam kandungan.

Pengertian Orang Tua Tiri, Berdasarkan Undang-undang nomor 23 tahun 2002 tentang perlindungan anak, masuk ke dalam kategori orang tua. Dapat dilihat dalam bab I ketentuan umum pasal 1 nomor 4, orang tua adalah Ayah dan/atau Ibu kandung, atau Ayah dan/atau Ibu tiri, atau Ayah dan/atau Ibu angkat.

\section{METODE PENELITIAN}

Metode pendekatan yang dilakukan dalam penelitian ini adalah metode yuridis normatif, yaitu Penelitian Hukum yang dilakukan dengan cara meneliti bahan pustaka atau data sekunder, bempa hukum positif dan bagaimana penerapannya dalam praktik di Indonesia.

\section{HASIL DAN PEMBAHASAN}

Pengaturan-pengaturan yang berkenaan dalam kasus perkosaan atau persetubuhan oleh ayah tiri terhadap anak dibawah umur diatur Pasal 287 KUHP, terdiri atas unsur-unsur:

a. Unsur-Unsur Subjektif : 
1. Yang ia ketahui

2. Yang sepantasnya harus ia duga

b. Unsur-Unsur Objektif :

1. Barang siapa

2. Mengadakan hubungan kelamin diluar pernikahan

3. Wanita yang belum mencapai usia lima belas tahun atau yang belum dapat dinikahi.

Diisyaratkan dua unsur subjektif secara bersama-sama yakni unsur yang ia ketahui dan unsur pidana yang sepantasnya harus ia duga di dalam rumusan tindak pidana yang diatur dalam pasal 287 ayat (1) KUHP, orang dapat mengetahui bahwa tindak pidana yang diatur dalam pasal 287 ayat (1) KUHP itu mempunyai unsur subjektif yang proparte dolus dan proparte culpa.

Pelaku dapat dinyatakan terbukti telah memenuhi unsur-unsur subjektif tersebut, baik penuntut umum maupun hakim harus dapat membuktikan bahwa pelaku memang mengetahui atau setidaktidaknya dapat menduga bahwa wanita yang mengadakan hubungan kelamin di luar pernikahan dengan dirinya belum mencapai usia lima belas tahun atau belum dapat dinikahi.

Pengetahuan atau dugaan pelaku tersebut ternyata tidak dapat dibuktikan di sidang pengadilan yang memeriksa dan mengadili perkara pelaku, maka hakim akan memberikan putusan bebas bagi pelaku.

Unsur objektif pertama dari tindak pidana yang diatur dalam pasal 287 ayat (1) KUHP ialah unsur barang siapa. Kata barang siapa menunjukkan pria, yang apabila pria tersebut memenuhi semua unsur dari tindak pidana yang diatur dalam pasal 287 ayat (1) KUHP, maka ia dapat disebut sebagai pelaku dari tindak pidana tersebut.

Unsur subjektif kedua dari tindak pidana yang diatur dalam pasal 287 ayat (1) KUHP ialah unsur mengadakan hubungan kelamin di luar pernikahan.

Terpenuhinya unsur ini oleh pelaku, tidaklah cukup jika hanya terjadi persinggungan di luar antara alat kelamin pelaku dengan alat kelamin korban, melainkan harus terjadi persatuan antara alat kelamin pelaku dengan alat kelamin korban, tetapi tidak diisyaratkan keharusan terjadinya ejaculatio seminis.

Terjadinya persatuan antara alat kelamin pelaku dengan alat kelamin korban itu saja, belum cukup bagi orang untuk menyatakan pelaku terbukti telah memenuhi unsur objektif kedua dari tindak pidana yang diatur dalam pasal 287 ayat (1) KUHP, karena disamping itu, undang-undang juga mensyaratkan bahwa persatuan antara alat-alat kelamin itu harus terjadi di luar pernikahan atau buiten echt

Sesuai yang dimaksud dengan pernikahan di dalam rumusan tindak pidana yang diatur dalam pasal 287 ayat (1) KUHP ialah pernikahan yang sah menurut undang-undang nomor 1 tahun 1974.

Pasal 2 dari undang-undang nomor 1 tahun1974 menetukan :

(1) Perkawinan adalah sah, apabila dilakukan menurut hukum masing-masing agamanya dan kepercayaannya itu. 
(2) Tiap-tiap perkawinan dicatat menurut peraturan perundang-undangan yang berlaku

Menurut Prof. Van Bemmelen dan Prof. Van Hattum, ketentuan pidana diatur dalam pasal 287 ayat (1) KUHP telah dibentuk untuk mencegah disalahgunakannya ketidakpengalaman anak-anak atau het misbruik maken van jeugdige onervarenheid oleh orang dewasa.

Itulah sebabnya,
$\begin{aligned} & \text { pembentuk } \\ & \text { telah }\end{aligned}$
melarang
dilakukannya perbuatan mengadakan
hubungan kelamin di luar pernikahan
dengan anak-anak yang belum mencapai
usia lima belas tahun atau yang belum
dapat dinikahi.

Secara kebetulan penentuan tentang usia wanita tersebut ternyata sesuai dengan penentuan tentang usia wanita yang belum diizinkan untuk menikah menurut Undang-undang No. 1 Tahun 1974, karena menurut ketentuan yang diatur dalam pasal 7 ayat (1) undang-undang nomor 1 tahun 1974, perkawinan itu hanya diizinkan jika pria telah mencapai usia 19 tahun dan pihak wanita telah mencapai usia 16 tahun.

Diisyaratkan unsur culpa yang oleh undang-undang telah dinyatakan dengan kata-kata van wie hij redelijkerwijs moet vermoeden atau yang sepantasnya harus ia duga di dalam rumusan tindak pidana yang diatur dalam pasal 287 ayat (1) KUHP memang tepat, karena jarang terjadi seorang pelaku dapat mengetahui dengan tepat mengenai usia wanita yang mengadakan hubungan kelamin dengan dirinya, kecuali jika wanita tersebut dapat menunjukkan akta identitasnya, misalnya dengan menunjukkan akta kelahirannya atau kartu tanda kependudukannya.

Pidana yang diatur dalam pasal 287 ayat (2) KUHP, undang-undang telah menentukan bahwa pelaku dari tindak pidana yang diatur dalam pasal 287 ayat (1) KUHP itu tidak akan dituntut kecuali jika ada pengaduan.

Pengaturan tentang perkosaan orang tua tiri terhadap anak dibawah umur sesuai KUHP, namun di luar KUHP juga terdapat 2 pasal diantaranya, yaitu:

A. Pasal $81 \quad$ Undang-undang nomor 23 Tahun 2002, yaitu :

(1) Setiap orang yang dengan sengaja melakukan kekerasan atau ancaman kekerasan memaksa anak melakukan persetubuhan dengannya atau dengan orang lain, dipidana dengan pidana penjara paling lama 15 (lima belas) tahun dan paling singkat 3 (tiga) tahun dan denda paling banyak Rp. 300.000.000,00 (tiga ratus juta rupiah) dan paling sedikit Rp. 60.000.000,00 (enam puluh juta rupiah).

Dalam pasal ini, pengaturan bagi pelaku perkosan terhadap anak di bawah umur dengan cara kekerasan ataupun ancaman kekerasan yang dimana menerangkan hukuman bagi pelaku sangatlah berat yaitu paling lama lima belas tahun penjara dan paling singkat tiga tahun penjara, setidaknya akan membuat pelaku geram dan menyadari benar perbuatan apa yang telah dilakukan. Pengaturan pada pasal ini sudah cukup efisien dalam menjerat para pelaku untuk dapat mempertanggungjawabkan perbuatannya di hadapan hukum. 
(2) Ketentuan

pidanan

sebagaimana dimaksud pada ayat (1) berlaku pula bagi setiap orang yang dengan sengaja melakukan tipu muslihat, serangkaian kebohongan, atau membujuk anak melakukan persetubuhan dengannya atau dengan orang lain.

Pasal ini menerangkan bahwa segala tindakan pemaksaan bersetubuh dengan seorang anak dengan cara tipu muslihat, serangkaian kebohongan atau bujuk rayu demi pemenuhan hasrat seksual pelaku terhadap anak yang menjadi korbannya. Hal tersebut seiring dengan berkembangnya teknik atau modus operandi pelaku perkosaan yang baru dan semakin berkembang yang antara lain dengan cara bujuk rayu, menipu, dan lain-lain. Dalam hal ini pelaku dapat diancam sama dengan pasal 81 ayat (1) yaitu minimal tiga tahun penjara dan maksimal lima belas tahun penjara.

B. Pasal 82 Undang-undang nomor 23 Tahun 2002, yaitu :

Setiap orang dengan sengaja melakukan kekerasan atau ancaman kekerasan, memaksa, melakukan tipu muslihat, serangkaian kebohongan, atau membujuk anak untuk melakukan atau membiarkan dilakukukan perbuatan cabul, dipidana penjara paling lama 15 (lima belas) tahundan paling singkat 3 (tiga) tahun dan denda paling banyak Rp. 300.000.000,00 (tiga ratus juta rupiah) dan paling sedikit Rp. 60.000.000,00 (enam puluh juta rupiah).

Faktor-faktor penyebab terjadinya perkosaan terhadap anak tiri yakni: Dari aspek psikologis sebagai salah satu aspek dari hubungan seksual adalah aspek yang mendasari puas atau tidak puasnya dalam melakukan hubungan seksual dengan segala aksesnya. Jadi bukanlah berarti dalam mengadakan setiap hubungan seksual dapat memberikan kepuasan, oleh karena itu pula kemungkinan akses-akses tertentu yang merupakan aspek psikologis tersebut akan muncul akibat dari ketidakpuasan dalam melakukan hubungan seks. Dan aspek inilah yang dapat merupakan faktor kekerasan seksual terhadap anak-anak yang menjadi korbannya.

Orang yang mengidap kelainan jiwa, dalam hal melakukan kekerasan seksual cenderung melakukan dengan sadis, misalnya seorang anak yang memendam dendam terhadap ibunya sejak kecil, sehingga kelak ia menjadi pelaku sadistis dalam hal kegiatan seksual, meski ia sendiri tidak mengalami kekerasan fisik.

Selain itu faktor kejiwaan seseorang bisa berubah sesaat akibat meminumminuman keras yang mengandung alkohol dapat beresiko melakukan kejahatan dengan mudahnya, sehingga perbuatan kejahatan tidak terkendali lagi.

Baik buruknya jiwa seseorang tergantung dari salah satu faktor yaitu faktor pendidikan yang diberikan kepadanya.Baik pendidikan di sekolah atau pendidikan dirumah sendiri maupun diluar sekolah.

Keburukan-keburukan dan ketidakteraturan maupun kekacauan pendidikan pengajaran yang dialami seseorang dalam perkembangannya dapat merangsang dan mempengaruhi tingkah laku seseorang itu kepada perbuatanperbuatan jahat. Apalagi kalau seseorang itu sama sekali tidak pernah mendapat pendidikan yang tidak teratur baik dari sekolah maupun dari orang tuanya besar pengaruhnya. 
Selain daripada itu juga kesalahan-kesalahan pendidikan dan pengajaran yang diberikan di sekolah dapat merangsang seseorang berbuat jahat, misalnya sistem pendidikan kolonial yang memperbesar sukuisme, penekanan kearah pendidikan dalam kehidupan demokrasi dsb. Juga kesalahan-kesalahan Guru atau Dosen di dalam memberikan pendidikan, misalnya penolakan atau pengusiran seseorang dari kelas, kebencian Guru atau Dosen terhadap seseorang, balas dendam Guru atau Dosen yang menimbulkan frustasi terhadap seseorang, demikian pula cara pendidiknya dan pengajaran yang hanya dilaksanakan dengan kekerasan, pukulan, hinaan, makian.

Selain daripada itu, contoh-contoh yang jelek yang diterima seseorang dari Guru atau Dosen, misalnya Guru atau Dosen yang sering main judi, berzinah, pemabuk, penipu, tukang gaduh (tingkah laku tidak sesuai dengan perbuatan). Sebaliknya pendidikan yang bermanfaat akan menjadikan seseorang itu mengerti dan memahami nilai-nilai : kesopanan, keagamaan, ketertiban, kedisiplinan, kekeluargaan, dan keindahan.

Dengan adanya norma-norma yang baik yang diajarkan pada diri seseorang akan menjadikannya berkualitas dan berpotensi menjadi harapan bangsa yang dapat membangun dan berkarya dalam mencapai cita-cita yang diinginkannya. Seseorang yang dalam lingkungan pendidikan yang baik akan mengisi hari-hari dengan hal yang positif yang dapat menunjang tingkat kecerdasan anak tersebut.

Dengan adanya kegiatan yang bersifat positif tersebut akan dapat memotivasi seseorang untuk selalu berbuat yang terbaik dalam kehidupannya dan tidak akan terjebak kepada perbuatanperbuatan yang akan merugikan masa depannya sendiri. Dengan melakukan kegiatan yang bermanfaat tersebut dapat mengembangkan kreatifitasnya dan dapat mencegah seseorang melakukan tindakan kejahatan sedini mungkin.

$\begin{array}{lcr}\text { C } & \text { PENERAPAN } & \text { HUKUM } \\ \text { PIDANA } & \text { TERHADAP } & \text { TINDAK } \\ \text { PIDANA } & \text { EKSPLOITASI } & \text { SEKSUAL } \\ \text { (PEMERKOSAAN) (STUDI PUTUSAN } & \text { PUTH } \\ \text { NOMOR: } & \text { 1599/PID. B/2007/PN Mdn) }\end{array}$

A. Kasus

Pada waktu dan tempat tersebut diatas, terdakwa mengajak saksi korban dan adik saksi korban yang bernama Oktri untuk tidur dikamar, kemudian sekitar pukul $02.00 \mathrm{Wib}$, saksi korban yang tidur diatas tempat bersama dengan terdakwa dan Devi terjatuh dari tempat tidur, terdakwa turun dari tempat tidur dan menggendong saksi korban untuk kembali ke tempat tidur, pada saat saksi korban telah diletakkan diatas tempat tidur, tiba-tiba terdakwa membuka celana dalam saksi korban dan merebahkan saksi korban di tempat tidur, selanjutnya terdakwa menindih saksi korban dari atas, kemudian saksi korban menangis namun terdakwa menyuruh saksi korban diam dan menutup mata serta mengancam saksi korban untuk tidak bilang ke orang lain, selanjutnya saksi korban yang merasa takut langsung diam dan terdakwa membuka celana terdakwa, untuk selanjutnya terdakwa menggesekgesekkan kemaluan terdakwa kekemaluan saksi korban sekitar 10 (sepuluh) menit hingga terdakwa orgasme, setelah selesai terdakwa memakaikan kembali pakaian 
ke saksi korban dan terdakwa memakai kembali pakaiannya untuk selanjutnya kembali tidur, pada pukul 08.00 Wib saksi korban mengadukan perbuatan terdakwa kepada saksi Esma Risma Sibarani untuk selanjutnya diteruskan perbuatan terdakwa ke Poltabes MS.

\section{Dakwaan}

1) Primair : Melanggar pasal 82 Undang-undang Republik Indonesia nomor 23 Tahun 2002 tentang perlindungan anak.

2) Subsidair : Melanggar pasal 81 ayat (1) Undang-undang Republik Indonesia nomor 23 Tahun 2002 tentang perlindungan anak.

\section{Pleedoi (pembelaan) Terdakwa}

Terdapat nota pembelaan (pleedoi) melalui kuasa hukumnya Irfan Surya Harahap dan Nurhijam yang tertulis :

Bahwa kami selaku penasehat hukum Terdakwa sebelumnya telah mengajukan Eksepsi yang ada pada intinya menyatakan bahwa pemeriksaan pada tingkat penyidikan terhadap terdakwa adalah tidak sah, hal ini dikarenakan pada waktu diperiksa oleh pihak penyidik kepolisian terdakwa pada saat itu tidak didampingi oleh penasehat hukum berdasarkan fakta tersebut penyidik telah melanggar maupun mengabaikan ketentuan-ketentuan pasal 54, 55, dan 56 KUHAP (kitab undangundang acara pidana).

Bahwa dalam proses pemeriksaan terdakwa, dengan jelas terdakwa telah menegaskan membantah seluruh sangkaan, dakwaan yang diajukan kepadanya dan membantah tuduhan bahwa terdakwa melakukan perbuatan seperti yang didakwakan kepadanya, serta dengan demikian terdakwa juga membantah seluruh keterangan yang telah diterangkannya dalam berita acara pemeriksaan (BAP) pada tingkat penyidikan di kepolisian.

Bahwa terdakwa dalam proses pemeriksaan di depan persidangan juga dengan tegas mengakui telah dipengaruhi dan dipaksa untuk menandatangani berita acara pemeriksaan (BAP) di kepolisian dan terdakwa juga mengakui pada saat itu merasa sendiri, ketakutan dan juga dalam keadaan tekanan psikologis yang tinggi karena tidak seorangpun mendampingi terdakwa apalagi dari penasehat hukum, saat itu tidak didampingi oleh penasehat hukum.

Bahwa proses pemeriksaan persidangan sampai saat ini tidak menghadirkan saksi Verbal Lisan yaitu pihak penyidik maka dapat diambil kesimpulan bahwa benar pada saat pemeriksaan pada tingkat penyidikan di kepolisian terdakwa telah dipengaruhi bahkan dipaksa untuk mengakui perbuatan tidak diperbuatnya dan juga dapat diambil kesimpulan bahwa benar terdakwa tidak didampingi penasehat hukum.

Bahwa dengan dinyatakannya oleh terdakwa telah dipengaruhi bahkan dipaksa untuk mengakui bahkan untuk menandatangani berita acara pemeriksaan (BAP) di kepolisian maka dasar untuk menyatakan terdakwa tidak bersedia untuk didampingi penasehat hukum dalam proses penyidikan menjadi gugur dan sampai saat ini pun belum ada bukti yang diajukan oleh saudara jaksa 
penuntut umum yang memang membuktikan terdakwa menolak untuk didampingi penasehat hukum dalam pemeriksaan di tingkat penyidikan, baik itu berupa surat pernyataan dari terdakwa maupun bukti-bukti lainya.

Bahwa dalam ketentuan KUHAP telah diisyaratkan pada setiap pemeriksaan baik pada tingkat penyidikan tersangka atau terdakwa wajib didampingi oleh penasehat hukum apalagi sangkaan yang dipersangkakan padanya saat itu adalah melanggar pasal-pasal yang diancam hukumannya sampai 15 (lima belas) tahun penjara, hal ini merupakan pengejawatahan dari hak-hak azasi manusia yang tentunya menjadi hak dari tersangka atau sekarang terdakwa.

Bahwa pelanggaran terhadap ketentuan pasal 54, 55, dan 56 KUHAP tersebut dengan sendirinya menyebabkan terdakwa tidak dapat dituntut sesuai dengan pasal-pasal yang dituduhkan kepadanya, hal ini sesuai dengan yurispudensi putusan Mahkamah Agung RI No. $1565 \mathrm{~K} / \mathrm{Pid} / 1991$, tertanggal 16 September 1993.

\section{Replik Jaksa Penuntut Umum}

Pada pokoknya tetap berpendapat tetap pada tuntutannya.

4. Pengadilan Negeri Medan (NOMOR: 1599/PID. B/2007/PN Mdn)

Majelis hakim memberikan pertimbangannya, yaitu :

Tentang fakta-fakta hukum :

Menimbang, bahwa dipersidangkan terdakwa pada pokoknya menerangkan sebagai berikut :
Bahwa benar pada tanggal 24 oktober 2006 terdakwa tidur bersama Haris, Devi, dan Oktri.

Bahwa pada waktu tengah malam abang Devi yaitu Haris pindah dan terdakwa tidur bersama Devi dan Oktri.

Bahwa lebih kurang satu jam setelah Haris pindah saksi mendengar ada suara jatuh dan ketika terdakwa lihat ternyata Devi (saksi korban).

Bahwa kemudian terdakwa angkat Devi ke tempat tidur dan Devi menangis katanya mimpi.

Bahwa ketika terdakwa tanya apakah ada yang sakit Devi menjawab tidak dan kemudian terdakwa dan Devi serta Oktri tidur sampai pagi.

Bahwa tidak benar pada malam tersebut terdakwa membuka celana Devi.

Bahwa berita acara pemeriksaan penyidik terhadap terdakwa tersebut tidak betul karena terdakwa ditekan polisi.

Menimbang, bahwa dipersidangan telah dibacakan Visum Et Repertum No. 31/OBG/2007 tertanggal 26 februari 2007 dari Rumah Sakit Umum dr. Pringadi yang ditanda tangani oleh dr. Syamsul Nasution, Sp.Og. yang menyatakan telah diperiksa Devi Oktaviani Sianturi alamat J1. Kapten Muslim No. 241 Kel. Helvetia Timur Kec.Medan Helvetia. Dalam Visum Et Repertum tersebut dinyatakan :

Genitalia : pada Hymen (selaput dara) dijumpai robek jam 9 (Sembilan), 12 (dua belas) sampai dasar. Dari kesimpulan Hymen (selaput dara) tidak utuh lagi.

Tentang Surat Dakwaan : 
$\begin{array}{rrr}\text { Menimbang, } & \text { bahwa karena } \\ \text { dakwaan Penuntut Umum bersifat }\end{array}$ alternative maka majelis hakim akan mempertimbangkan dakwaan yang tepat sesuai dengan perbuatan yang dilakukan oleh terdakwa yaitu dakwaan subsidair sebagaimana diatur dalam pasal 81 ayat (1) UU No. 23 Tahun 2002.

Menimbang, bahwa pasal 81 ayat (1) UU No. 23 Tahun 2002 unsurunsurnya sebagai berikut :

a. Setiap orang

b. Dengan sengaja melakukan kekerasan atau ancaman kekerasan

c. Memaksa anak melakukan persetubuhan dengannya atau dengan orang lain.

1. Unsur setiap orang.

Menimbang, bahwa dalam praktek peradilan hingga kini masih diperdebatkan apakah unsur setiap orang atau lazim dirumuskan dengan kata "Barang Siapa" merupakan unsur atau bukan dalam suatu rumusan tindak pidana, namun lepas dari perdebatan yuridis tersebut sesuai dengan kebiasaan praktek peradilan dan ataupun memorie van toelicting menjelaskan bahwa yang dimaksud dengan unsur setiap orang atau barang siapa adalah manusia sebagai subjek hukum.

Menimbang, bahwa terdakwa dipersidangkan pada pokoknya telah menerangkan bahwa keseluruhan identitas yang tercantum dalam dakwaan Penuntut Umum dibenarkan oleh terdakwa, maka tidak dapat diragukan lagi bahwa terdakwa adalah orang yang dapat dikualifikasikan sehat akal pikirannya dan mampu mempertanggung jawabkan perbuatannya secara hukum hal tersebut dikaitkan pula dengan keterangan saksi-saksi yang telah diajukan di persidangan oleh karena itu majelis hakim sependapat dengan Penuntut Umum bahwa unsur "setiap orang" telah terpenuhi.

2. Unsur dengan sengaja melakukan kekerasan atau ancaman kekerasan.

Menimbang arti sengaja menurut teori pengetahuan adalah kehendak untuk berbuat dengan mengetahui akibat perbuatannya.

Menimbang dengan sengaja dalam perkara ini berarti terdakwa harus mempunyai niat, maksud atau mempunyai tujuan untuk melakukan persetubuhan dengan saksi korban Devi Oktaviani Sianturi.

Menimbang, bahwa yang dimaksud dengan kekerasan yaitu membuat orang pingsan atau tidak berdaya lagi (lemah) yang artinya mempergunakan atau kekuatan jasmani tidak kecil secara tidak sah sedangkan tidak berdaya artinya tidak mempunyai kekuatan atau tenaga sama sekali sehingga tidak dapat mengadakan perlawanan sedikit pun.

Menimbang, bahwa dipersidangan terdakwa menerangkan tidak melakukan persetubuhan dengan saksi korban Devi Oktaviani Sianturi akan tetapi dalam pemeriksaan terdakwa di depan penyidik terdakwa mengaku telah melakukan persetubuhan dengan saksi korban dan pengakuhan tersebut karena terdakwa ditekan polisi dalam hal ini penyidik.

Menimbang, bahwa sesuai dengan yurispudensi Putusan Mahkamah Agung tanggal 20-9-1967 No. 177 K/Kr/1965 
yang menyatakan pengakuan-pengakuan para tertuduh I dan II dimuka polisi dan jaksa dalam hubungan satu sama lain dapat dipergunakan sebagai petunjuk untuk menetapkan kesalahan para tertuduh dan Putusan Mahkamah Agung tanggal 23-2-1960 No. 229 K/Kr/1959 yang menyatakan pengakuan dicabut tanpa alasan yang berdasar, merupakan petunjuk tentang kesalahan terdakwa.

Menimbang, bahwa perbuatan yang dilakukan terdakwa yaitu melepas celana dalam saksi korban kemudian menyetubuhi saksi korban Devi Oktaviani Sianturi dan saksi masih berumur 10 tahun maka tentunya antara terdakwa dan saksi korban kekuatan fisik sangat jauh berbeda. Dan dalam persidangan saksi korban menerangkan waktu disetubuhi terdakwa badannya ditindih oleh terdakwa dan korban hanya bisa bilang sakit dan tidak mampu berbuat lainnya dengan tujuan menggagalkan perbuatan terdakwa akan tetapi terdakwa tetap melakukan perbuatannya.

3. Unsur memaksa anak melakukan persetubuhan dengannya atau dengan orang lain.

Menimbang, bahwa sesuai dengan keterangan saksi korban pada tanggal 24 Oktober 2006 jam 02.00 Wib sewaktu tidur bersama bapaknya (terdakwa), saksi korban celananya dilepas oleh terdakwa, menggesek-gesekkan kemaluannya dikemaluan saksi korban dan saksi korban bilang sakit "pa" tetapi terdakwa berkata tutup mulutmu.

Menimbang, bahwa di persidangan saksi Esma Risma Sibarani dan saksi Maryam Br Pasaribu.Paginya mendapat cerita dari saksi korban tentang perbuatan terdakwa pada malam tersebut.
Menimbang, bahwa di persidangan terdakwa tidak mengaku telah menyetubuhi saksi korban akantetapi dalam pemeriksaan di depan penyidik terdakwa mengaku telah berbuat cabul dengan saksi korban.

Menimbang, bahwa di persidangan telah dibacakan Visum Repertum No.31/OBG/2007 tertanggal 26 Februari 2007 dari Rumah sakit Umum Dr. Pringadi yang ditanda tangani oleh Dr. Syamsul Nasution, Sp. OG yang menyatakan telah diperiksa Devi Oktaviani Sianturi alamat Jl. Kapten Muslim No. 241 Kel. Helvetia Timur Kec.Medan Helvetia.

Dalam Visum Repertum tersebut dinyatakan, Genitalia : pada Hymen (selaput dara) dijumpai robek jam 3 (tiga), tidak sampai dasar. Pada hymen (selaput dara) dijumpai robek jam 9 (Sembilan), 12 (dua belas) sampai dasar.Kesimpulan hymen (selaput dasar) tidak utuh lagi.

Menimbang, bahwa sesuai dengan yurispudensi Putusan Mahkamah Agung tanggal 20-9-1967 No. 177 K/Kr/1965 dan putusan Mahkamah Agung tanggal 23-2-1960 No. $229 \quad \mathrm{~K} / \mathrm{Kr} / 1959$ sebagaimana dalam pertimbangan unsur kedua di atas karena dalam persidangan terdakwa tidak terbukti telah dianiaya oleh penyidik maka keterangan terdakwa dapat dipakai sebagai alat bukti petunjuk.

Menimbang, bahwa walaupun di depan penyidik terdakwa mengaku berbuat cabul pada saksi korban tetapi bila dikaitkan dengan Visum Repertum majelis berpendapat bahwa perbuatan yang telah dilakukan terdakwa kepada saksi korban adalah persetubuhan dengan paksaan. 
Menimbang, bahwa berdasarkan pertimbangan-pertimbangan di atas maka unsur ketiga telah terpenuhi.

Menimbang, bahwa karena semua unsur-unsur pasal 81 ayat (1) UU no. 23 Tahun 2002 terpenuhi maka kepada terdakwa haruslah dinyatakan terbukti dengan sah dan meyakinkan bersalah dalam pasal 81 ayat (1) UU no. 23 Tahun 2002.

Menimbang, bahwa oleh karenanya majelis hakim tidak sependapat dengan penasehat hukum terdakwa pada nota pembelaannya bagian primair yang menyatakan terdakwa agar dibebaskan dari segala tuntutan hukum.

Menimbang, bahwa karena terdakwa terbukti dengan sah dan meyakinkan bersalah melakukan tindak pidana sebagaimana diatur dan diancam pidana dalam pasal 81 ayat (1) UU No. 23 Tahun 2002 maka kepada terdakwa harus dijatuhi pidana.

Menimbang, bahwa karena terdakwa ditahan maka selama terdakwa berada dalam tahanan dikurangkan seluruhnya dengan pidana yang dijatuhkan dalam dictum putusan ini.

Menimbang, bahwa karena terdakwa dijatuhi pidana maka kepada terdakwa dibebani pula membayar biaya perkara.

Menimbang, bahwa selama persidangan tidak diketemukan adanya alasan pemaaf dan pembenar yang dapat meghapuskan pertanggungjawaban pidana oleh terdakwa.

Menimbang, bahwa sebelum menjatuhkan putusan dan akan dipertimbangkan hal-hal yang memberatkan dan meringankan.

Hal-hal yang memberatkan :

- Perbuatan terdakwa mengakibatkan masa depan saksi korban menjadi suram.

- Selaku ayah tiri dan guru terdakwa seharusnya melindungi dan menjadi panutan saksi korban tetapi terdakwa justru melakukan perbuatan tercela yang menimpa saksi korban.

- Terdakwa dalam memberikan keterangan dipersidangan berbelitbelit.

Hal-hal yang meringankan :

- Terdakwa belum pernah dihukum.

- Terdakwa selaku kepala keluarga dan mempunyai tanggungan anak-anak yang masih kecil.

Mengingat Undang-undang yang bersangkutan khususnya pasal 81 ayat (1) UU No. 23 Tahun 2002 tentang Perlindungan anak.

\section{Putusan Hakim}

Hakim telah menyatakan bahwa Edward Maruli Aritonang (terdakwa) terbukti bersalah melakukan persetubuhan dengan anak tirinya yaitu Devi Oktaviani Sianturi dengan kekerasan memaksa anak melakukan persetubuhan dengannya.

Hakim juga menjatuhi terdakwa dengan pidana penjara selama 10 (sepuluh) tahun dan beserta denda Rp. 80.000.000, (delapan puluh juta rupiah) dengan ketentuan apabila denda tersebut tidak dibayar diganti dengan pidana kurungan selama 3 (tiga) bulan. 


\section{B. Analisa kasus}

Setelah penulis membaca dan menganalisa Putusan Pengadilan Negeri Medan dengan no. 1599/Pid.B/2007/PN. Mdn, maka dari kasus tersebut penulis dapat berkesimpulan sebagai berikut :

Tuntutan Jaksa Penuntut Umum :

Sesuai dalam surat dakwaannya, penuntut umum menuntut hukuman penjara dan denda sesuai dalam pasal 81 ayat (1) dan pasal 82 UU no. 23 Tahun 2002 tentang perlindungan anak, dan hakim telah mengabulkan tuntutan tersebut sesuai dengan tuntutan jaksa penuntut umum.

Putusan Hakim :

dengan penuntut umum sama menghukum terdakwa dengan pasal 81 ayat (1) UU no. 23 Tahun 2002 tentang perlindungan anak. Dalam hal ini hakim memutuskan untuk menghukum terdakwa dengan pasal 81 ayat (1) karena sudah jelas diterangkan "setiap orang yang dengan sengaja melakukan kekerasan atau ancaman kekerasan memaksa anak melakukan persetubuhan dengannya atau dengan orang lain".

Sudah cukup jelas bahwa setiap orang maksudnya adalah pelaku, pelaku yang dalam hal ini orang yang melakukan tindak pidana. Serta dengan sengaja melakukan kekerasan atau ancaman kekerasan untuk melakukan kekerasan atau ancaman kekerasan telah terpenuhi, karena terdakwa secara langsung menindih korban dengan tubuhnya, sehingga korban tidak dapat berontak yang berusia 10 tahun, tentu tidak mampu melawan orang dewasa dan dengan ancaman "tutup mulutmu dan matamu" kata-kata tersebut, sebenarnya menimbulkan tekanan psikis juga karena mengingat anak berusia 10 tahun dan seorang perempuan, dalam hal ini katakata diatas kurang dipertegas untuk bahan tambahan dalam dakwaan jaksa walaupun sedikit disinggung.

Dan sudah jelas unsur yang terakhir "melakukan persetubuhan", persetubuhan dalam hal ini adalah berhubungan badan atau intim. Sedangkan dalam pasal 82 UU no.23 Tahun 2002 tentang perlindungan anak, hakim berkesimpulan lain dengan jaksa penuntut umum, karena unsur dalam pasal 82 terlalu meluas. Yang kata kuncinya "melakukan tipu muslihat, serangkaian kebohongan, atau membujuk anak untuk melakukan atau membiarkan dilakukan perbuatan cabul" jelas dalam pasal 82 ini terlalu meluas sedangkan dalam kasus tidak tertulis serangkaian perkataan untuk melakukan tipu muslihat, kebohongan, dan membujuk, melainkan pemaksaan yang dilakukan secara langsung tanpa adanya unsur membujuk atau sebagainya.

Kasus posisi dan Bukti-bukti :

Perkosaan atau pencabulan dalam kasus ini merupakan eksploitasi secara anomi dan/ atau seksual dalam surat dakwaan jaksa penuntut umum. Dalam posisi kasus bila dihubungkan dengan bukti-bukti, terdakwa memang telah melakukan perbuatan perkosaan atau pencabulan tersebut, karena terdakwa telah mengakui perbuatannya, serta bukti bahwa saksi korban menceritakan kronologisnya, dan bukti terakhir yang menguatkan adalah adanya hasil Visum Et Repertum No.31/OBG/2007 tanggal 26 
Februari 2007 yang ditanda tangani oleh Dr. Syamsul Nasution, Sp.OG. telah kita ketahui ketiga bukti yang kuat tersebut, maka dapat disimpulkan tindak pidana ini telah terpenuhi.

Tentang fakta-fakta hukum pendukung lain yang menyebutkan bahwa dipersidangkan terdakwa pada pokoknya menerangkan sebagai berikut :

Bahwa benar pada tanggal 24 oktober 2006 terdakwa tidur bersama Haris, Devi, dan Oktri.

Bahwa pada waktu tengah malam abang Devi yaitu Haris pindah dan terdakwa tidur bersama Devi dan Oktri.

Bahwa lebih kurang satu jam setelah Haris pindah saksi mendengar ada suara jatuh dan ketika terdakwa lihat ternyata Devi (saksi korban).

Bahwa kemudian Devi terdakwa angkat ke tempat tidur dan Devi menangis katanya mimpi.

Bahwa ketika terdakwa tanya apakah ada yang sakit Devi menjawab tidak dan kemudian terdakwa dan Devi serta Oktri tidur sampai pagi.

Bahwa tidak benar pada malam tersebut terdakwa membuka celana Devi.

Bahwa berita acara pemeriksaan penyidik terhadap terdakwa tersebut tidak betul karena terdakwa ditekan polisi.

Bahwa dipersidangan telah dibacakan Visum Et Repertum No. 31/OBG/2007 tertanggal 26 februari 2007 dari Rumah Sakit Umum dr. Pringadi yang ditanda tangani oleh dr. Syamsul Nasution, Sp.Og. yang menyatakan telah diperiksa Devi Oktaviani Sianturi alamat
J1. Kapten Muslim No. 241 Kel. Helvetia Timur Kec.Medan Helvetia. Dalam Visum Et Repertum tersebut dinyatakan.

Dapat kita telaah bahwa hakim telah mempertimbangkan berdasarkan fakta hukum yang ada dapat kita simpulkan dakwaan oleh jaksa penuntut umum sudah cukup memenuhi unsurunsur yang sesuai dengan pasal 81 ayat 1 undang-undang nomor 23 tahun 2002 tentang perlindungan anak.

Setelah penulis perhatikan mengapa seorang penuntut umum tidak memasukkan pasal 287 dan 294 KUHP, adalah :

Dalam pasal 287 memang benar menyebutkan perempuan yang bukan isterinya, belum cukup 15 tahun, tetapi sudah sepatutnya ia tahu bahwa anak tersebut belum dewasa karena anak tirinya dan masanya belum pantas untuk kawin, namun belum terlalu signifikan dan sesuai karena pelaku adalah orang tua (ayah tiri).

Dalam pasal 294 memang benar bahwa seorang ayah tiri tersebut melakukan persetubuhan dengan anak yang belum dewasa, anak tiri, anak peliharaannya, yang telah dipercayakan kepadanya untuk menanggung anak tersebut, untuk dididik dan dijaga.

Jadi alasan penuh mengapa jaksa tidak menaruh pasal 287 dan 294 KUHP melainkan memakai pasal 81 ayat1 dan pasal 82 undang-undang nomor 23 tahun 2003 tentang perlindungan anak. Dimana alasan yang lebih mendetail sesuai dengan asas lex spesialis de rogat lex generalis dengan kata lain kekuatan hukum umum mengenyampingkan kekuatan hukum khusus atas teori itulah 
yang membuat KUHP dapat dikesampingkan karena sudah ada yang lebih signifikan dari KUHP maka hakim dengan sah dan meyakinkan dengan memutuskan dengan pasal 81 ayat 1 undang-undang nomor 23 tahun 2003.

Walaupun hakim sudah sesuai dengan putusan yang telah didakwakan kepada terdakwa namun hal-hal yang memberatkan dapat lagi ditambahkan sesuai pemikiran penulis, seperti: Mengakibatkan kondisi mental si anak menjadi terganggu dan menimbulkan ketakutan sendiri bagi kejiwaan si anak.

Namun seperti pengakuan serta kronologis kejadian bahwa si terdakwa atau ayah tiri tersebut sebenarnya belum terpikir untuk menanamkan niatnya bersetubuh dengan anak tirinya tesebut, namun akibat faktor dari intern dalam hal ini adalah keluarga yang utuh, dimana si terdakwa sebenarnya membutuhkan pendamping untuk memanjakan maupun memuaskan hasratnya, dalam hal ini ibu dari korban Devi Oktaviani Sianturi, tetapi berimbas pada anaknya.

\section{SIMPULAN}

Seharusnya dalam hal menanggan perlindungan anak kiranya dapat berjalan dengan baik, apa yang telah ditentukan oleh undang-undang sebagai hukum kiranya dapat direalisasikan dengan dilakukannya penyuluhan kepada masyarakat bahwa terdapat aturan hukum dalam hal perlindungan anak dimana undang-undang telah memberikan tanggung jawab kepada orang tua atau wali, keluarga, masyarakat, pemerintah, pemerintah daerah, bahkan negara, untuk turut serta dalam penyelenggaraan perlindungan terhadap anak

\section{DAFTAR PUSTAKA}

A Buku-buku

Badrul zaman, Mariam Darus, Aneka Hukum Bisnis, Baandung: Alumni, 1994.

Chazawi, Adami, 2002, Pelajaran Hukum Pidana 1, Jakarta: PT Raja Grafindo Persada. 2005, Tindak pidana Mengenai Kesopanan, Jakarta: PT Raja Grafindo Persada.

Gandhy, Mahmud, 1986, Kedudukan Pers dalam Hukum Indonesia, Jakarta: Andess.

H. Hari Sahordji, 1980, Pokokpokok Kriminologi, Jakarta: Aksara Baru.

Hasibuan, Ridwan , Edi Warman, 1994, Asas-asas Kriminologi, Medan: USU Press.

Kartono, Kartini, 1982, Psikologi Anak, Bandung: Alumni.

Lamintang, P.A.F., Samosir, C. Djisman, 1985, Hukum Pidana Indonesia, Cetakan Kedua.

Lamintang, 2009, Delik-Delik Khusus Kejahatan Melanggar Norma Kesusilaan \& Norma Kepatutan, Jakarta: Sinar Grafika.

Marlina, 2009, Peradilan Pidana Anak di Indonesia, Bandung: PT Refika Aditama.

Komplikasi Hukum Jaminan, Bandung: MAndar Maju, 2004.

B. Peraturan Perundang-Undangan 
Pidana

Kitab Undang-Undang Hukum

Kitab Undang-undang Hukum Acara Pidana

Undang Nomor 35 Tahun 2014 Tentang Perubahan Atas Undang-Undang Nomor 23 Tahun 2002 Tentang Perlindungan Anak.

Undang-Undang Nomor.11 Tahun 2012 Tentang Sistem Peradilan Pidana Anak.

C. Internet

Lubis, Muhammad Ansori, Perlindungan Hukum terhadap Anak Nakal Berdasarkan UU Nomor 11 Tahun 2012 tentang Sistem Peradilan Anak, Jurnal RETENTUM Universitas Darma Agung VOLUME 1 Nomor 1 Agustus 2019 diakses tanggal Jurnal\%20ANSORI\%20LUBIS.pdf pada tanggal 1 Juni 2019.

Devi, Ria Sintha, Tinjauan Yuridis Perceraian atas Perkawinan yang
Tidak tercatat di Dinas Kependudukan dan Pencatatan Sipil Kota Medan, jurnal retentum Volume 1 Nomor 1 Agustus 2019 diakses pada tanggal September 2019

https://orbitdigitaldaily.com/70persen-anak-di-sumut-alami-kekerasanseksual/ diakses pada tanggal 1 Juni 2019 Pukul 23.00 WIB.

file://C:/Users/Master/Downloads /Kekerasan-terhadap-anak.pdf diakses pada tanggal 25 Juni 2019 Pukul 22.00 WIB.

https://www.komnasperempuan.g o.id/file/pdf_file/Modul\%20dan\%20Pedo man/Kekerasan\%20Seksual/15\%20BTK $\%$ 20KEKERASAN\%20SEKSUAL.pdf diakses pada tanggal 27 Juni Pukul 22.10 WIB. 